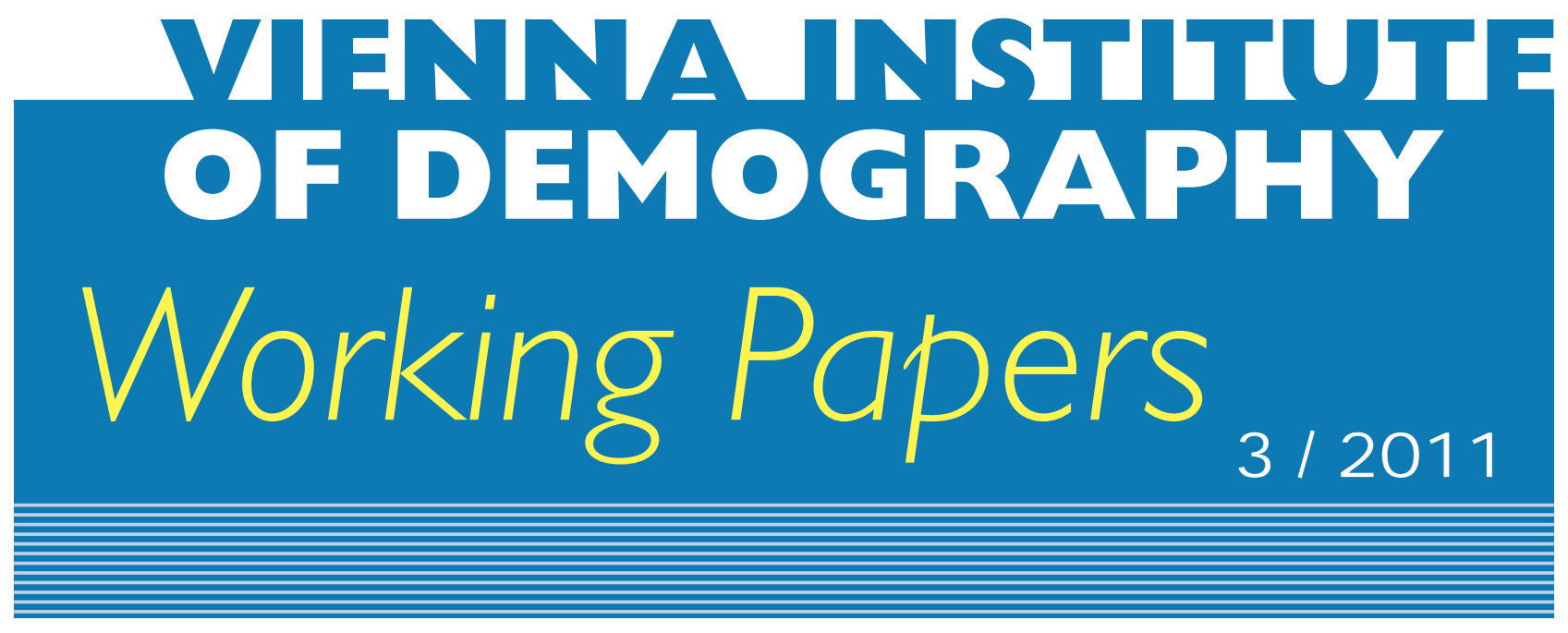

Isabella Buber and Katrin Fliegenschnee

\title{
Are you Ready for a Child? A M ethodological Triangulation on Fertility Intentions in Austria
}

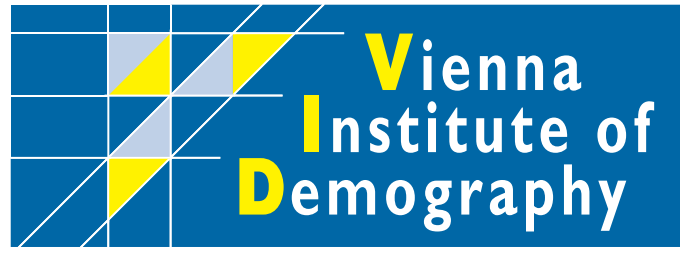

Vienna Institute of Demography Austrian Academy of Sciences

Wohllebengasse 12-14

A-I040Vienna $\cdot$ Austria

E-Mail:vid@oeaw.ac.at

Website: www.oeaw.ac.at/vid 


\begin{abstract}
Research on fertility has been mainly using quantitative methods, and it is only in the last few decades that qualitative research methods have become more common in demography. Combining qualitative and quantitative methods in a so-called triangulation is even more uncommon. Applying a triangulation, the current paper aims to better understand the concept of fertility intention with regard to family formation. During problem-centred interviews with childless men and women, the issue of feeling ready was mentioned again and again. It turned out that apart from economic circumstances, this individual aspect is important for the decision to have a child. In this paper, we explain the rather complex concept of feeling ready using interviews. Based on these qualitative results, additional questions were included in the Austrian "Generations and Gender Survey" (GGS) which allow to analyse the dimension of being ready also quantitatively in a national representative dataset. Our results clearly support the theory of planned behaviour in the context of family formation, as social norms, attitudes and behaviour control are significantly associated with childbearing intentions. In the contextual framework of the theory of planned behaviour, our quantitative results revealed that the feeling of being ready has additional explanatory power for childbearing intentions among childless men and women in Austria.
\end{abstract}

\title{
Keywords
}

Fertility intentions, triangulation, mixed methods, theory of planned behaviour, Austria, GGS

\section{Authors}

Isabella Buber is a research scientist at the Vienna Institute of Demography (Austrian Academy of Sciences), Wittgenstein Centre for Demography and Global Human Capital. Email: isabella.buber@,oeaw.ac.at

Katrin Fliegenschnee is a research scientist at the Vienna Institute of Demography (Austrian Academy of Sciences), Wittgenstein Centre for Demography and Global Human Capital. Email: katrin.fliegenschnee@,oeaw.ac.at

\section{Acknowledgements}

We want to thank Caroline Berghammer, Maria Rita Testa and Christian Wegner for helpful comments as well as Jane Klobas and Dimiter Philipov for an intensive theoretical discussion. We are also grateful to Sylvia Trnka and Werner Richter for language editing.

The Austrian GGS was conducted by Statistics Austria with the financial support of the Federal Ministry of Economy, Family and Youth, the Federal Ministry of Science and Research and the Federal Ministry of Labour, Social Affairs and Consumer Protection. The international GGS templates (survey instruments, sample design) were adapted to the Austrian context by the Vienna Institute of Demography and the Austrian Institute for Family Studies. The Austrian Institute for Family Studies has also coordinated the Generations and Gender Programme for Austria. 


\title{
Are you Ready for a Child? A Methodological Triangulation on Fertility Intentions in Austria
}

\author{
Isabella Buber and Katrin Fliegenschnee
}

\section{Introduction}

Family formation processes and fertility decisions are complex. Demographic characteristics, socioeconomic and individual aspects, societal norms as well as attitudes are crucial for fertility plans and decisions. Research on fertility has been mainly using quantitative methods, and only in the last decades, qualitative research methods have become more accepted in demography (e.g. Bernardi 2003; Bernardi, Keim and Von der Lippe 2007; Settersten 2007; Rille-Pfeiffer 2009; Borchardt and Stöbel-Richter 2004; Bernardi, Klärner and Von der Lippe 2008; Keim, Klärner and Bernardi 2009; Von der Lippe 2010). Blossfeld and Huinink (2001, p. 10) have argued that 'soft' data are often missing which could help to better understand the intention towards fertility. They indicate that a combination of qualitative and quantitative research might help to better understand life cycle events. Combining qualitative and quantitative methods in a so-called triangulation, the current paper analyses childbearing decisions taken by childless men and women in Austria.

Some researchers have mentioned the aspect of being ready for a child, but typically address the issue when discussing quantitative or qualitative results (e.g. Blossfeld and Huinink 2001; Settersten 2007). To our knowledge, this aspect has never been addressed explicitly in family research. During problem-centred interviews with childless men and women in Vienna on family plans, partnership and further related aspects, the issue of feeling ready was mentioned again and again. It turned out that apart from economic circumstances, this individual aspect is important for the decision to have a child (Fliegenschnee 2006a). In this paper, we explain the rather complex concept of feeling ready. Based on these qualitative results, additional questions were included in the Austrian "Generations and Gender Survey" (GGS) which allowed analysing the dimension of being ready also quantitatively in a national representative dataset. In the framework of the theory of planned behaviour (TPB), we studied the feeling of being ready as a determinant for childbearing decisions as well as its impact on childbearing intentions of childless men and women in Austria.

\section{Theoretical Background}

The theoretical framework of our quantitative analyses is the social-psychological TPB by Ajzen and Fishbein (Ajzen 1988, 1991; Ajzen and Fishbein 2005). The TPB was adapted to fertility and is implemented in the GGS (Vikat et al. 2007). Fundamental for the TPB is the assumption that the intention to perform a specific behaviour is the proximate antecedent of the behaviour itself. In the context of fertility, the intention to have a child can be seen as the proximate antecedent of having a child, which would be the act of behaviour. ${ }^{1}$ The TPB has

\footnotetext{
${ }^{1}$ As Billari, Philipov and Testa (2009, p. 443) point out, it may be questionable to see having a child as an act of behavior, "given the complex sequence of acts that separates the decision to have a child from actual childbearing." The authors refer to the term proceptive behavior, contrary to contraceptive behavior. The main
} 
been recently used for analysing fertility decisions and intentions based on the GGS (e.g. Billari, Philipov and Testa 2009; Dommermuth, Klobas and Lappegard 2009; Klobas 2010).

According to the TPB approach, intentions - in our case, fertility intentions - are described as being directly dependent on three conceptually independent determinants: attitudes towards the behaviour, social norms and perceived behavioural control (Figure 1). These three dimensions are crucial within the TPB. Background factors (e.g. individual factors such as personality, experiences, emotions or age) influence the construction of intentions via effecting attitudes, subjective norms and perceived behavioural control (Ajzen and Fishbein 2005).

\section{Figure 1}

Schematic presentation of the theory of planned behaviour

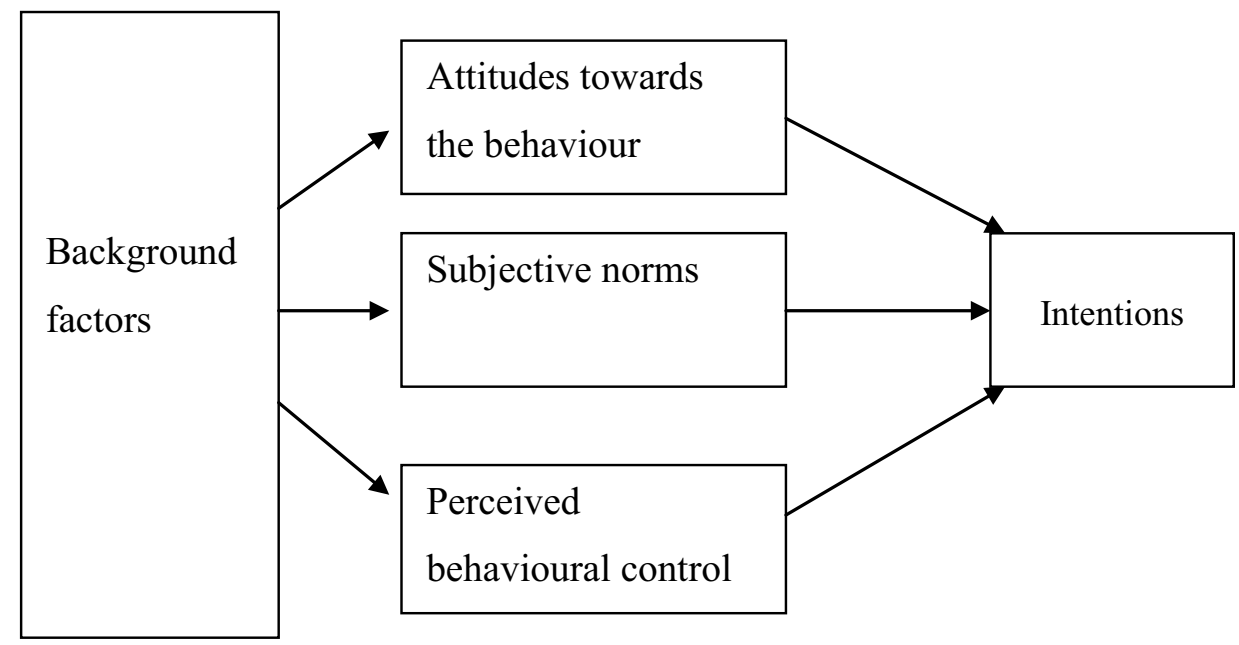

Source: Ajzen and Fishbein 2005, p. 194

We briefly describe the three components of the TPB. First, it is assumed that intentions depend on attitudes towards a special behaviour (i.e. having a child) and on how much a person favours this behaviour (Ajzen 1991). Following this approach individuals evaluate if the behaviour (i.e. having a child) will have a positive or a negative outcome (consequences) for them (Ajzen and Fishbein 2005). The second predictor is a social factor termed subjective norms. Norms refer to social pressure of significant others to perform or not perform a certain behaviour (i.e. having a child) (Ajzen 1991). In the recent literature normative pressure is described as a key element of childbearing decisions. Important individuals (e.g. parents, friends, relatives) will approve or disapprove a certain behaviour (i.e. having a child), which influences fertility intentions (Billari, Philipov and Testa 2009; Dommermuth, Klobas and Lappegard 2009; Philipov et al. 2009). The third antecedent of intention is the degree of perceived behaviour control which encompasses constraints that individuals are aware of (Ajzen 1991). It refers to people's perception of facilitation or difficulties regarding the behaviour in question and is assumed "to reflect past experience as well as anticipated impediments and obstacles“ (Ajzen 1991, p. 188). Typically constraints which hinder having

point of departure is that, in high-contraception societies, and especially in lowest-low fertility context, contraception is the default behaviour, and fertility behaviour can be seen as proceptive (Miller and Pasta 1995). 
a child like income, labour force status or education are researched (Billari, Philipov and Testa 2009). Perceived behavioural control has only recently been considered as a potential factor for explaining intentions (Billari, Philipov and Testa 2009).

\section{Empirical Evidence}

Previous studies have addressed fertility intention in connection with the TPB. Liefbroer (2005) examined the impact of perceived costs and rewards of having a child on the actual timing of entry into parenthood among Dutch young adults. The expected costs and rewards were found to influence the timing of parenthood among both women and men. Dommermuth, Klobas and Lappegard (2009) argued that attitudes towards children have no significant effect on the timing of a birth among childless individuals in Norway. Contrary to this finding, Billari, Philipov and Testa (2009) showed that attitudes, norms and perceived behaviour control are simultaneous determinants of fertility intentions in Bulgaria, even when background factors are controlled for. However, perceived behaviour control only mattered for second births. Both research papers found a very strong effect of subjective norms and significant others, especially for the first birth. Age was pointed out to have a strong effect on the timing of childbearing. Additionally it was noticed that women have stronger childbearing intentions than men (Dommermuth, Klobas and Lappegard 2009).

Some researchers have mentioned the aspect of being ready for a child (e.g. Blossfeld and Huinink 2001; Settersten 2007). Blossfeld and Huinink (1991) found that women postpone their entry into motherhood because of the normative expectation that they are 'not ready' for having a child when still rather young and in education. Miller and Pasta (1994, p. 232) argued that the most desirable item about the timing of children was "having a child when $\mathrm{s} /$ he by her/himself and the spouse is personally ready".

The ongoing German panel survey PAIRFAM (Panel Analysis of Intimate Relationships and Family Dynamics) includes the aspect of being ready (Huinink et al. 2010), but to our knowledge this aspect has not been explicitly analysed so far. Although results based on a minipanel preceding this survey revealed that for women being ready is a relevant precondition for the intention to have a child within the next two years, the authors discuss mainly economic and structural aspects influencing the readiness. The emotional dimension of 'being ready' is not elaborated (Huinink, Schröder and Boehnke 2008; Maul, Huinink and Schröder forthcoming).

Several qualitative studies emphasised the feeling of being mature enough to take over responsibility for children (e.g. Bernardi 2003; Settersten 2007; Müller-Burhop 2008). In an investigation of the different types of social mechanisms responsible for the interdependence of couples' reproductive preferences, Bernardi (2003, p.528) cited a married couple who agreed on waiting until they "felt mature as a couple". Similarly, Settersten (2007) stated that for many people being mature and ready for a child was regarded as a requirement to become a parent. They concluded that many individuals postpone their fertility plans because they are aware of the responsibility of being a parent and they want to perform this role well. Moreover, Settersten (2007) underlined that individuals felt completely grown up when having entered parenthood. Having a child was regarded as a key element of adulthood. Regarding family formation, it turned out that for women preconditions are more relevant than for men. In particular, the readiness of the partner, financial safety and their own working conditions are important (Huinink, Schröder and Boehnke 2008). In the context of 
fertility intentions, Borchardt and Stöbel-Richter (2004) found in their qualitative research that some interview partners did not mention socio-economic determinants but talked about their own and their partner's development.

Being prepared might be regarded as related to being ready. In a recent qualitative study on Austria, Rille-Pfeiffer (2009) argued that women and men want to get prepared for having a child and want to have perfect conditions when entering parenthood. Additionally people want to make ideally a couple decision, which means that the partners have to agree about details.

In the previous literature, the aspect of readiness was discussed in the context of family formation, but to our knowledge, it has not been analysed comprehensively. The current paper focuses on this issue in more detail. Starting with qualitative methods, we elaborate the term 'being ready' and explain in which context childless men and women mention this aspect. Based on our qualitative results, we formulate research hypotheses which are tested in the quantitative part of our paper in a conceptual model based on the TPB.

\section{Methodology of Triangulation}

Although the division between qualitative and quantitative research is entrenched in the core disciplines of social sciences, researchers have proposed ways to integrate the two approaches (Fielding and Fielding 1986; Flick 2004). Scientists have shown how these approaches complement each other and are increasingly using a combination of both methods - known as "methodological triangulation" (Denzin 1989) - to provide a more holistic view of a specific topic. The term triangulation was used first by Campbell and Fiske (1959), the title being drawn from the world of surveying, where measurements are taken from three or more different points in order to identify more accurately a particular area. Therefore, a triangulation can be seen as a tool to provide information in different settings about the same research question. For a typology we refer to Denzin (1989) who identified four types of triangulation: data, investigator, theoretical and methodological. As we combine qualitative and quantitative methods, we applied a methodological triangulation ${ }^{2}$ but refer to the notation of 'triangulation' in the remainder of the paper.

Our mixed methods design focused on the family formation process as well as on fertility intentions of childless men and women in Austria. The triangulation of quantitative and qualitative methods is highly useful both for the research process and for the epistemological development of a research question (Flick 2006). The results of the qualitative and the quantitative research are complementing each other and yield a comprehensive picture (Flick 2006). The starting point was a qualitative approach. Qualitative methods are "superior when one wishes to explore a topic more fully" (Begley 1996, p. 122). One advantage of qualitative research is that people can talk about their behaviour and intentions in their own words, and explain them from their personal point of view. However, the results are limited to a rather small group that was under research. Out of the qualitative data, theoretical ideas and hypotheses were developed and additional questions were included into the Austrian version of the GGS to allow further analyses with quantitative methods. In this way, we aimed to

\footnotetext{
2 To be more exact, Denzin (1989) described two types of methodological triangulations: within-method and across-method. According to his typology, we applied an across-method triangulation. For a brief overview of Denzin's typology we refer to Begley (1996).
} 
obtain deeper explanations of the same phenomenon (Kelle 2001). We used descriptive statistics as well as probit regressions to test our hypotheses in the nationally representative GGS dataset.

\section{Qualitative Research}

\subsection{Problem-Centred Interviews and Sampling}

The intention of our paper is to get a better understanding of how fertility intentions are generated. We used problem-centred interviews (Witzel 2000). The following issues were discussed during the interviews: plans for family and children, partnership, interviewees' families of origin, social networks as well as values, personal aims and the topic of fears and uncertainty. All interviews started with a narrative part. The guideline changed somewhat over the research. However, most of the participants were asked "When you think back how did the issue of having a child come up the first time?" After the narration immanent questions $^{3}$ were asked, followed by questions about topics that were not mentioned by the interviewed person but which were also necessary for the research (Lamnek 1995; Mayring 1990; Flick 1995). People talked freely about their idea of having children, about what was important for them and what they considered as necessary to prepare. In a qualitative interview, the focus is on the interviewee and what s/he considers as important regarding the open question. Because interviewing and analysing are interlinked and not separated processes, the centre of interest changed over time, although the main topics remained the same.

During the whole project 'theoretical sampling' was used (Glaser and Strauss 1967). All in all we conducted 21 interviews between 2005 and 2007. The interviewed persons were between 24 and 42 years old, childless and had been living with their current partner for at least three years. Twelve women and nine men (each a partner of one of the interviewed women) were interviewed. All participants were interviewed separately. Interviews lasted between 90 minutes and two hours. We started with more highly educated individuals and during the theoretical sampling process included also less educated respondents (for more information see Appendix).

\subsection{Qualitative Analysis}

In this study the method of qualitative sequence analysis (Froschauer and Lueger 1992) was linked with the coding principles of grounded theory (Strauss and Corbin 1996). Applying sequence analysis, we used 'rough analysis' to develop hypotheses which were checked and continuously reviewed. This method is used especially to detect important structural characteristics (Froschauer and Lueger 1992). Considering grounded theory we worked with the coding principles of 'open coding', 'axial coding' and 'selective coding' (Strauss and Corbin 1996). The main task in the analysing process was to develop categories and hypotheses.

\footnotetext{
${ }^{3}$ Immanent questions are subsequent questions on topics raised by the respondents which require clarification.
} 
Applying qualitative sequence analysis has the advantage that a certain number of hypotheses and ideas are already developed before starting with coding principles of grounded theory. While analysing with objective hermeneutic sequence analysis, small sequences ${ }^{4}$-which are units of interaction - are looked at to elaborate the 'Gestalt' (which means the shape or pattern) of the segment. Hypotheses are developed to explain structural aspects as well as the relation to the respondent's environment. Rules or patterns of behaviour become visible which gives us information about the overall 'meaning structures' of the individual (Maiwald 2005). Hypotheses about the social world as well as about the interview situation are formed and permanently reviewed during the analysing process (Froschauer and Lueger 1992). During open coding small sequences are analysed by considering, for example, what the sequence is about, in which way an interviewee talks about an issue, which persons are mentioned, which issues are not mentioned. In this process, categories as well as a concept are developed which describe a phenomenon and its context. Similar elements are grouped together and by doing that, the categories become comprehensive. The categories change during the research process to reach conceptual density and to exceed the descriptive level (Strauss 1991). During the process of axial coding, connections between the categories are made to develop linkages between the different categories (Strauss and Corbin 1996). The described qualitative approach is not a linear process but a circular one. This also holds true for the analysing process, where sequence analysis, open coding and axial coding were used alternately and not stepwise.

\subsection{Results}

The analyses of the qualitative interviews revealed that individuals have a vision about what their lives should look like in the future. These visions and ideas are very important for the fertility decision. The decision for a child will be made when the reality is rather close to the ideal picture of what one's life with a child should look like (Fliegenschnee 2006b).

Since attitudes toward behaviour, social norms and perceived behaviour control are crucial in the TPB, we want to point out that these issues were raised in our qualitative data. Our interviewees talked a lot about what consequences a child would bring about. The question of when to have a child, and how childless men and women perceive their role as mothers or fathers, were very strongly connected with social norms. In addition, all interviewees reflected their own financial situation. Those who seriously considered taking parental leave discussed their job in detail. By contrast, work was not an issue for males who did not consider the idea of staying at home with the child for some time. The job situation of the woman as future mother, however, was discussed by all participants. Although financial issues were mentioned, our findings indicate that they do not seem to be the most important issue when it comes to entering parenthood.

The preconditions and how they are perceived were regarded as important but they were not seen as the crucial element for entering parenthood.

Well, yes, I think, at the moment our preconditions (for having a

child) would be rather good. (Florian, male, 28 years)

\footnotetext{
${ }^{4}$ Sequences can be whole sentences, parts of sentences or single words.
} 
This person pointed out several times during the interview that even if the conditions would be found they would not want to have a child now.

What turned out to be crucial was the feeling of being ready. This aspect was mentioned time and again and turned out to be one of the key elements when it comes to the decision for having a child. We concentrate on this aspect and do not elaborate further the determinants of the TPB mentioned above. The issue of 'feeling ready' and feeling stable and settled enough to be a parent was mentioned with a lot of emphasis by nearly all interviewees. In our definition the concept of 'feeling ready' basically means that one has to be confident that it is the right decision at that particular point in time.

... because then we really want to get fully and deliberately involved and now both of us still are more or less in the phase of finding ourselves. (Günther, male, 29 years)

When becoming a parent people need to shift a lot of attention away from themselves towards someone else, i.e. the child (Settersten forthcoming). Several interviewed persons argued that they wanted to be stable and settled enough so that they can focus on this other person. The feeling to be emotionally ready to make such a step was perceived as very important.

... that you really want to have (children) and that you are prepared to spend time with the child and to invest emotionally (into the child). (Daniela, female, 34 years)

Readiness was often related to maturity and adulthood. To feel ready also means changing from youth to adulthood. Helfferich, Klindworth and Kruse (2005) also found that becoming a father was connected with being adult. When people talked freely about having a child they very often pointed out that they needed to be ready and mature to take over the new role of a mother or father.

... that you need to have an idea, meet certain standards, that you want to educate your children well and be a good father, and I thought I am not yet ready for that. (Martin, male, 33 years)

The older the interviewed persons were the more convinced they were of being mature. Nevertheless, the subjective age and the subjective feeling of being adult enough differed considerably. For example, one 24 year old man was fully convinced that he was already adult enough for having a child whereas another of 34 talked at length about not being ready yet. We have to point out that these two men had different social backgrounds, were living in different worlds so to say. Both needed to be grown up enough to have the feeling of being ready for such a step, to assume a new role and to be good in it. Regarding the notion of maturity, we again refer to a qualitative study on reproductive preferences by Bernardi (2003) who cited a highly educated Italian couple, married for seven years, aged 31 and 37 years, who agreed on waiting until feeling mature as a couple. This example further illustrates that the feeling of being mature is rather subjective and less dependent on objective age.

Throughout our interviews, the decision for a child was regarded as a couple's joint decision. In this context, the feeling to be ready as a couple is also important. It was perceived that both need the feeling that being a parent would fit into their lives. 
One reason is that, at the moment, we simply do not yet see

ourselves able to ... see ourselves as parents. (Florian, male, 28

years)

The emphasis on the dyadic perspective is in line with Burkart (1994) and a recent study by Rille-Pfeiffer (2009) who found that couples want to find the ideal point in time for both partners. In our current study it turned out that especially for women their own readiness as well as that of their partners was very important.

His sister asked us "when will you have a child". I didn't reply, you know, what should I say-Alex does not want to? (laughs). As for me, I am ready to have one anyhow. (Silvia, female, 30 years)

Whereas women strongly emphasised the couple perspective, for men the readiness of their female partner tended to be more important than their own. This is in line with Borchardt and Stöbel-Richter (2004) who argued that males concede more autonomy to women regarding the decision when to have a child. Also, Rille-Pfeiffer (2009) found in her research that women take the dominant part in the discussion about fertility timing. In other words, the word of the woman was described as a bit more important than that of the man.

But I clearly stated my views or wishes about this, and now it is up to her to decide. (Franz, male, 42 years)

It turned out clearly that the individuals not only reflected their own feelings but-quite intensively - also the situation of the other.

Several males reported that they were afraid of being unable to fulfil their own needs with a child. Another person, i.e. the child, would be at the centre of interest and reduce their own personal freedom, an issue that mainly men considered as important in family formation.

... but also mature in the sense that you can shelve your own needs and lifetime wishes (when you have a child). (Martin, male, 33 years)

The idea that a child is associated with many sacrifices and that future parents have to be ready for this was mainly discussed by men. Women talked more about the fact that they wanted to experience several things before becoming a mother. Especially younger females talked more about this issue.

The opinions of others were discussed with respect to the family formation process and the feeling of being ready. Recent studies showed that the influence of significant others is likely to have an effect on fertility intentions (Billari, Philipov and Testa 2009; Dommermuth, Klobas and Lappegard 2009). In the following quotation a woman refers to 'other' people than close ones. She argues that expectations of others who are emotionally not important to her, affect her feeling of being ready.

I think you need a thick skin, that others may think you are an uncaring mother if you do not stay at home the whole time (...).

I guess I am not ready for this, I have to cotton on to this idea so that 
I will have a thick skin at the time (when I have a baby). (Manuela, female, 27 years)

The feeling of being ready referred not only to personal aspects, but also to economic ones, including one's own working and educational situation. This holds true for men as well as for women. Both need to be ready and to feel safe also economically to start a family.

He wants to finish his studies, he points out that he is not ready for such ideas before finishing his studies. (Silvia, female, 30 years)

Not only education but also other complex details need to be clear. To finish one thing means also to be ready for something new. To have a child is a very new part in life which means that many things should be finished and clarified before.

We illustrated what we understand by the concept of feeling ready. It is a rather complex issue with many elements. It includes confidence in being mature enough, to be ready to invest emotionally into a child, to be a good parent and therefore one has to be prepared. Not just one partner but the couple as such must be ready for such a step. When a child is there its needs are of utmost importance and other things have to be reduced, individual and personal needs of the parents taking a back seat. Having a child is regarded as something one must be ready for. Childless persons would often point out that they feel that others will judge them and the way they live their lives - therefore they want to prepare themselves for being a mother or a father. In addition to this rather emotional readiness, issues like finishing education and study courses were pointed out as well. For the interviewees it was rather difficult to talk about this because it is based on the feeling of being mature enough, which is a state of mind that is not clearly defined. Even if it is difficult to capture all aspects of this personal feeling of being ready for a child, we incorporated that aspect in the Austria GGS to further elaborate it in a quantitative framework.

Based on our qualitative research, we formulate four hypotheses:

H 1: The feeling of being ready is an important determinant for fertility intentions.

H 2: The feeling of being ready is not gender-specific and perceived by men and women in the same way.

H 3: The feeling of being ready is more important for childbearing intentions than economic aspects.

H 4: The feeling of being ready has further explanatory power for childbearing decisions in the multifaceted framework of the TPB.

\section{Quantitative Research}

\subsection{Data}

The quantitative part of the study is based on the Austrian GGS, carried out in 2008/09. The current study uses information on 2,086 childless individuals (999 men and 1,087 women) aged 18 to 44 years who were able to conceive a child but did not expect one at the time of the interview and had consistent information on their childbearing intentions. Throughout the analyses, weights were applied (Buber 2010). For reasons of data availability, research on fertility and family formation used to be focused on women, and only in the last 
few decades have studies also included men. The GGS allows profound analyses of the family formation process and the determinants of childbearing decisions among Austrian men and women.

The international GGS questionnaire includes questions on childbearing intentions as well as possible factors for childbearing decisions. With regard to childbearing intentions, three dimensions are captured, namely the intention to have a(nother) child (1) now, (2) within the next three years, as well as (3) the general intention to have a child, for those who do not want to have a(nother) child within the next three years. As intentions become more meaningful when the time remaining for their actual realisation is short and that time interval is specified (Philipov, Speder and Billari 2006; Schoen et al. 1999), we follow the approach to concentrate on the intention to have a child within the next three years (e.g. Billari, Philipov and Testa 2009). In line with our qualitative data we focus on childless people. Intentions to have a first child are intentions to become a parent, whereas intentions to have a second or third child are affected by previous life-course experience regarding parenthood (Hobcraft and Kiernan 1995).

Apart from childbearing intentions, respondents were asked how much their decision on whether or not to have a(nother) child during the next three years depends on several factors. ${ }^{5}$ These factors include economic indicators (one's financial situation, one's own and the partner's work situation, housing conditions), partner-related aspects (having a suitable partner), health as well as structural conditions (availability of child care, opportunities to go on parental leave). These items were incorporated in the general GGS in the framework of the TPB, described in the previous section (see also Vikat et al. 2007), and they capture aspects of perceived behaviour control (see also Dommermuth, Klobas and Lappegard 2009; Klobas 2010). Based on our qualitative results on childbearing behaviour (Fliegenschnee 2006a), additional individual aspects were included in the Austrian GGS which refer to the dependence of childbearing decisions on: (1) the feeling of being ready for a child, (2) the partner's readiness for a child, and (3) the feeling of being ready for a child as a couple. The quantitative study focuses on the importance of readiness as well as on various other aspects for fertility intentions and on how they possibly influence fertility decisions.

\subsection{Results}

The basic demographic characteristics indicate that our sample includes rather young adults. Two out of three childless persons were under the age of 30, the men's mean age being slightly higher than the women's (27.5 versus 26.7 years) (Appendix Table A1). Only one out of three individuals in our sample were living with a partner, another $22 \%$ had a partner without sharing the household (i.e. living apart together, LAT), and a substantial proportion reported no partner (45\%). Childless men more often had no partner $(50 \%)$ than childless women $(39 \%)$. The interviewed childless women were more highly educated than their male counterparts, with $23 \%$ of the women (and $15 \%$ of the men) holding a tertiary degree (ISCED $5+6)$.

\footnotetext{
${ }^{5}$ The exact wording is: "How much would the decision on whether or not to have a/another child during the next three years depend on the following." Possible answers: (a) not at all, (b) a little, (c) quite a lot, (d) a great deal, (e) not applicable.
} 
In a first descriptive analysis, we addressed the importance of perceived behavioural control among childless Austrian men and women, concentrating on: economic factors (material control), personal control and 'being ready'. Regarding economic factors (Figure 2), one's financial situation determines to a certain extent one's fertility decisions: for roughly four out of ten women and men, the decision to have or not to have a child in the near future depends to a great deal or quite a lot on their own financial situation. Women see their financial situation more often as a strong factor than men (44\% versus $38 \%)$. In addition, for women their own job is an important determinant (45\%), whereas men do not attribute as much importance towards their own job (28\%). Comparing women's evaluation of their own work with men's evaluation of their partner's work, our results indicate that women assess their own work more often as an important factor than men view their partner's work ( $45 \%$ versus $31 \%$; see Table A2 in the Appendix). Unfortunately, we are not able to analyse couples and can compare these numbers only with caution. Nevertheless, our numbers indicate a somehow different evaluation of women's work for childbearing decisions among childless men and women. A further indicator of material control included in the GGS refers to housing conditions. It is for roughly one out of three women and men an important criterion in the childbearing decision process (Table A2 in the Appendix).

Turning to personal control and the feeling of being ready, we find higher agreement towards these determinants as compared to material control (Figure 2). Almost eight out of ten childless women and men answered that a suitable partner determines to a great deal or quite a lot the decision for or against a child. Moreover, the three items on readiness additionally included in the Austrian GGS were also ranked as important determinants. The respondent's and the partner's feeling of being ready for a child and especially the couple as a unity being ready for a child were regarded as crucial for fertility decisions (Table A2 in the Appendix). What is more, the aspect of being ready even tends to be more often ranked as a crucial determinant for fertility decisions than a suitable partner, as our first descriptive results reveal that for $80 \%$ of childless men and $85 \%$ of childless women the feeling of being ready for a child as a couple (Figure 2) was an important determinant, as compared to $78 \%$ and $77 \%$, respectively, for the question about a suitable partner. As expected, the three included items on the feeling of being ready show high correlation, with a factor ranging from 0.80 to 0.89 among men and women. The evaluation of a suitable partner correlates less with the items of being ready $(0.50$ to 0.56$)$.

Our descriptive analyses reveal also gender-specific differences regarding the feeling of being ready. As was the case for material control, women also considered readiness more often than men to be a strong determinant for their childbearing decisions. In addition, we find that whereas for men the partner's readiness is more important than their own feeling of being ready $^{6}$, for women being ready as a couple is slightly more important than their personal feeling, or their partner's feeling, of being ready ${ }^{7}$. These findings match with the qualitative results. However, both sexes clearly consider the decision for a child to be a couple's decision. In the remaining part of our quantitative analysis, we concentrate on only one aspect of being ready, namely on the feeling of being ready as a couple, since the three items of being ready are highly correlated and since it is the aspect with the highest approval.

\footnotetext{
${ }^{6} 78 \%$ versus $70 \%$, see Table A2 in the Appendix.

${ }^{7} 85 \%$ versus $82 \%$ and $81 \%$, see Table A2 in the Appendix.
} 


\section{Figure 2}

Dependence of childbearing decision on selected factors of perceived behaviour control and readiness

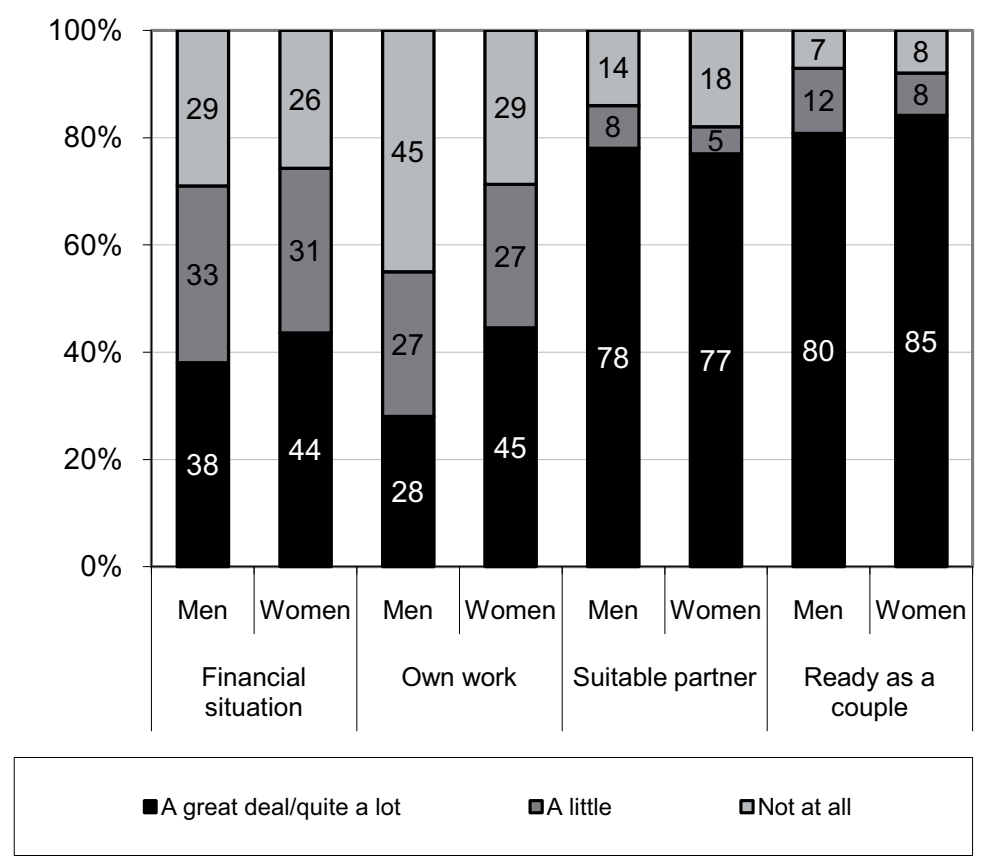

Source: Austrian GGS 2008/09; weighted data; N = 2,086 childless persons

Remark: The question on partner's work was posed to all persons, i.e. also to those who had no partner at the time of the interview.

Other aspects of personal control concern the respondents' own and their partners' health. Moreover, child care availability and parental leave opportunities capture further facets of perceived behavioural control. We do not further elaborate on these items in our bivariate analyses since we focus on material control, personal control and the feeling of being ready. Generally, they were regarded less often as important determinants compared to the feeling of being ready (see Table A2 in the Appendix). Nevertheless, they are included in the multivariate setting embedded in the TPB.

We explore descriptively the association between perceived behaviour control and readiness on the one hand and age on the other (Figure 3). It turns out that one's financial situation and one's own work are more important at younger ages as their relevance in the decision process decreases substantially with age. Among childless men in the age group 40 to 45 years, material control is important to only a rather small group (16-20\%), whereas childbearing decisions of their female counterparts depend more often on the women's own financial situation (30\%) and work situation (39\%). Our bivariate findings indicate that among childless women in their early forties, their own work becomes more important again. We might assume that these women have succeeded in setting up a working career until the age of forty which - at least for some of them - is difficult to combine with children.

Whereas external factors referring to material control lose importance in the decision process, a suitable partner and the issue of being ready remain highly important throughout the midthirties and decrease only in the 35-44 age group. Although the feeling of being ready as a couple and a suitable partner are less often regarded as important in the decision-making 
process of childless persons in their late thirties and early forties, these two dimensions remain the most frequently cited determinants. For example, for roughly two out of three childless men and women aged 40 to 45 years the childbearing decision still depends "to a great deal" or "quite a lot" on a suitable partner and the feeling of being ready as a couple, whereas one's own work and financial situation lost importance for the decision-making process.

\section{Figure 3}

Importance of selected factors for childbearing decision by age groups

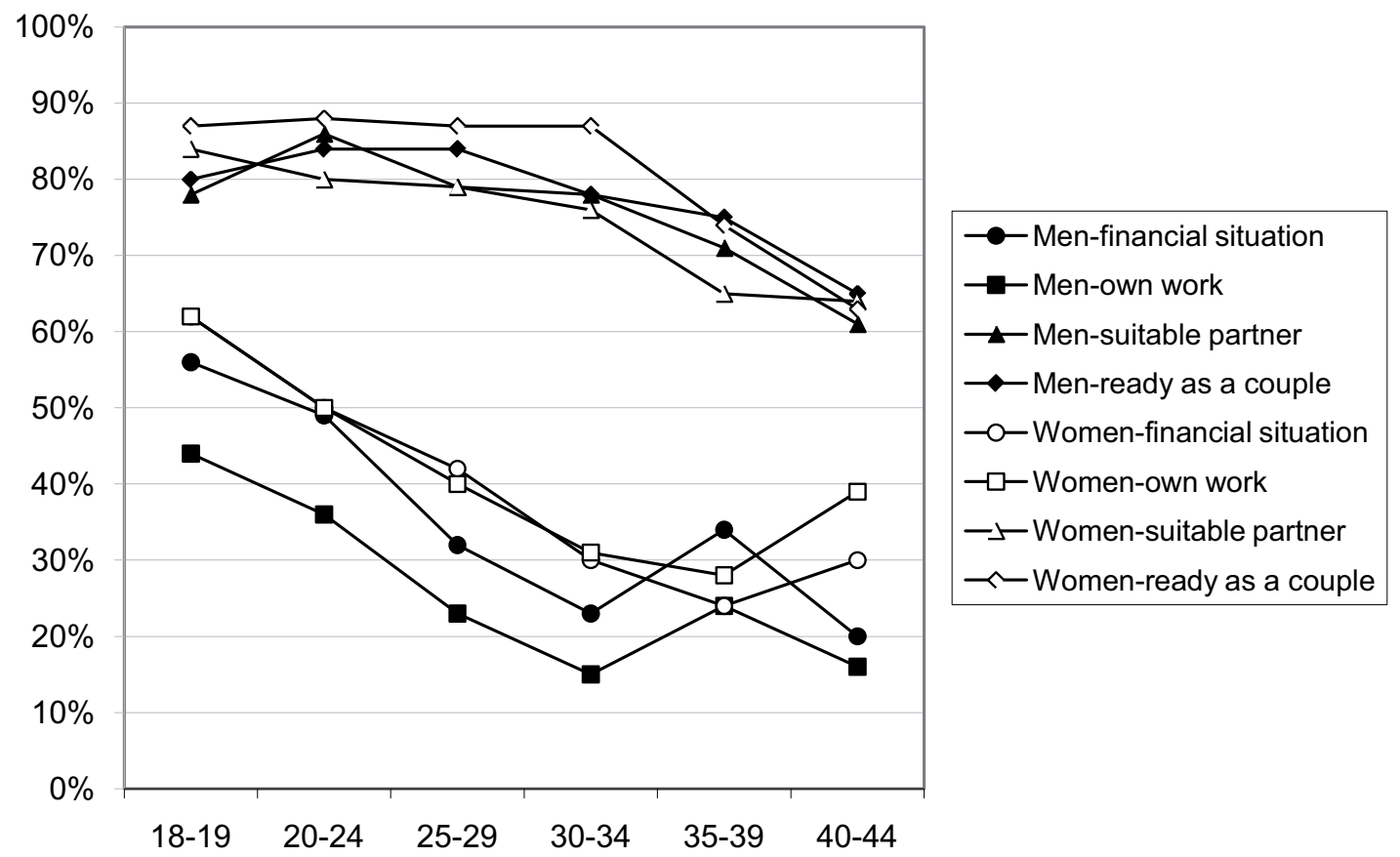

Source: Austrian GGS 2008/09; weighted data; $N=2,086$ childless persons

Remark: Percentage of persons for whom the selected factors determines to "a great deal" or "quite a lot" the decision on whether or not to have a child within the next three years.

To sum up, our descriptive analyses indicate that both material control and personal control as well as the feeling of being ready have an impact on the decision process for a child. Interestingly enough, personal control and the - additionally included - feeling of being ready are more often than economic or health-related aspects seen as crucial in the decision process for or against a child within the near future. ${ }^{8}$

\footnotetext{
${ }^{8}$ Although we concentrate on childless individuals, we briefly report the results on mothers and fathers as well. The experience of parenthood and the number of children is a major factor that determines childbearing and we therefore conducted parity-specific analyses. We find that among parents economic factors are to about the same degree considered as strong determinants for childbearing decisions, with the respondents' own jobs being less often considered as an important determinant among mothers as compared to childless women. Among parents, however, a suitable partner and the feeling of being ready are to a much lower extent evaluated as important factors for the decision to have a child in the near future. Moreover, individual factors become less important with increasing parity but stay on a rather high level compared to other factors.
} 
In a next step, we analyse the aspect of being ready in a multivariate setting and link the feeling of being ready with fertility intentions. As described above, we included the importance of being ready for individual childbearing intentions. Unfortunately, we did not ask whether the respondent (the partner and - if appropriate - the couple) actually felt ready for a child. We are therefore unable to weight the importance of being ready. Due to this data restriction, we can analyse the aspect of being ready only empirically but not theoretically. Nevertheless, we want to find out, with the limited data we have, whether readiness does add something from an empirical point of view.

As mentioned earlier, the conceptual framework of our quantitative study is based on the TPB. The GGS includes several questions to operationalise the TPB, namely norms, attitudes and perceived behavioural control. Following Billari, Philipov and Testa (2009) and Dommermuth, Klobas and Lappegard (2009), we applied factor analysis to reduce the set of observed variables. Since we concentrate on specific aspects of behavioural control, we applied factor analysis only to the items referring to norms and attitudes. We kept all the different aspects of behavioural control separately in order to be able to analyse its various dimensions. Factor analysis based on childless persons in Austria revealed three factors which are in line with results based on Bulgarian (Billari, Philipov and Testa 2009) and Norwegian data (Dommermuth, Klobas and Lappegard 2009). We followed the notation by Dommermuth and colleagues and named these three factors "norms", "positive attitudes" and "negative attitudes". For details on the factor analysis we refer to Table A3 in the Appendix.

In a multivariate setting, childbearing intentions within the next three years is the dependent variable of interest. Using a probit regression model, the intention to definitely or probably want to have a child within the next years was opposed to the intention to definitely or probably not want to have a child within this time span. In total, $37 \%$ wanted to have a child within the next three years, varying between $61 \%$ among those living with a partner, $40 \%$ among men and women living apart together with their partner and $24 \%$ for those who had no partner at the time of the interview.

We included the above-mentioned factors derived from the TPB, as well as readiness. Moreover, further demographic aspects such as sex, age and partner status were added as control variables. Analyses were run for the overall sample including all childless persons as well as for men and women separately to explore possible gender differences (Table 1). As expected, age and partner status are relevant for childbearing plans. The intention to start a family in the near future is highest among childless persons in their early thirties and lowest in early adulthood (Table 1, column 1). Whereas childless men in the 40-45 age group still have comparably high intentions for family formation, childless women of the same age group have significantly lower childbearing intentions than younger ones (Table 1, columns 2 and 3 ). We might speculate that their childlessness is more often wanted or accepted - partly due to consecutive postponement of childbearing plans - whereas childless men in the early forties more often plan a family. Our results confirm the well-known influence of partner status on childbearing intentions within the near future. Especially those without a partner have significantly low childbearing intentions. In the state of living apart together, family formation intentions are attenuated among men as compared to those living with the partner in the same household. Among women, on the other hand, those not sharing the household with their partner do not indicate lower childbearing intentions compared to cohabiting women. We might conclude that living apart together does not hinder the family formation plans of childless women in Austria, but it does for men. In the overall model we find that childless 
women significantly more often want to start a family within the next three years compared to men (Table 1, column 1).

The factors capturing norms and positive as well as negative attitudes are highly significant for childbearing intentions. Therefore, our results support the TPB in the context of childbearing intentions.

Let us now turn to the different aspects of behavioural control. In the overall model including men and women (Table 1, column 1), one's own work, a suitable partner, child care availability and parental leave opportunities are aspects of perceived behaviour control which are significantly associated with the intention to have a child in the near future. But analyses run separately for men and women reveal gender-specific differences. The descriptive finding that among women the respondent's own work situation was more often regarded as important for childbearing decisions than among men is confirmed in the multivariate framework. Childless women who declared their own work to be important for imminent childbearing decisions significantly less often wanted to have a child during the next three years, as compared to those for whom their own work was not that relevant (Table 1, column 3). The estimated coefficient in the male sample is lower and not statistically significant (Table 1, column 2). Moreover, in the multivariate model, the importance of a suitable partner significantly influences the childbearing intentions of childless women but not so for childless men. 


\section{Table 1}

Estimated coefficient for the intention to have a first child within the next three years, probit regression

All childless Childless men Childless women

\begin{tabular}{|c|c|c|c|}
\hline \multicolumn{4}{|l|}{ Age } \\
\hline $18-24^{\mathrm{a}}$ & 0 & 0 & 0 \\
\hline $25-29$ & $0.64 * * *$ & $0.53 * * *$ & $0.81 * * *$ \\
\hline $30-34$ & $0.84 * * *$ & $0.71 * * *$ & $1.03 * * *$ \\
\hline $35-39$ & $0.57 * * *$ & $0.55^{* * *}$ & $0.70 * * *$ \\
\hline $40-44$ & 0.09 & $0.40 *$ & $-0.42+$ \\
\hline \multicolumn{4}{|l|}{ Partner status } \\
\hline No partner & $-0.82 * * *$ & $-0.72 * * *$ & $-1.04 * * *$ \\
\hline Living with partner in same household ${ }^{\mathrm{a}}$ & 0 & 0 & 0 \\
\hline Living apart together & $-0.18^{*}$ & $-0.30 *$ & -0.06 \\
\hline \multicolumn{4}{|l|}{$\operatorname{Sex}$} \\
\hline Male $^{\mathrm{a}}$ & 0 & & \\
\hline Female & $0.27 * * *$ & & \\
\hline \multicolumn{4}{|l|}{ Factors for theory of planned behaviour } \\
\hline Norms & $0.30 * * *$ & $0.29 * * *$ & $0.31 * * *$ \\
\hline Negative attitudes & $0.46^{* * *}$ & $0.45 * * *$ & $0.50 * * *$ \\
\hline Positive attitudes & $0.31 * * *$ & $0.16^{* *}$ & $0.52 * * *$ \\
\hline \multicolumn{4}{|l|}{ Perceived behavioural control } \\
\hline Financial situation & -0.01 & -0.20 & 0.09 \\
\hline Own work & $-0.34 * * *$ & -0.19 & $-0.39 * *$ \\
\hline Housing conditions & 0.10 & $0.23 *$ & 0.00 \\
\hline Own health & -0.03 & -0.14 & 0.10 \\
\hline Suitable partner & $0.25^{*}$ & 0.18 & $0.39 *$ \\
\hline Partner's work & 0.10 & -0.02 & $0.26+$ \\
\hline Partner's health & 0.08 & 0.07 & 0.05 \\
\hline Child care availability & $-0.18^{*}$ & $-0.20+$ & -0.11 \\
\hline Parental leave opportunities & $0.19^{*}$ & $0.26^{*}$ & 0.01 \\
\hline Ready as a couple & $0.21 *$ & 0.21 & $0.28+$ \\
\hline Constant & $-1.04 * * *$ & $-0.80 * * *$ & $-1.05 * * *$ \\
\hline Pseudo $\mathrm{R}^{2}$ & 0.32 & 0.26 & 0.42 \\
\hline Number of observations used & 2,023 & 975 & 1,048 \\
\hline
\end{tabular}

Significance: $+\mathrm{p}<0.10 ; * \mathrm{p}<0.05 ; * * \mathrm{p}<0.01 ; * * * \mathrm{p}<0.001$.

${ }^{a}$ Reference category.

Remark: Education turned out to have no explanatory power in our model. We therefore did not include it in our final model presented here

Source: GGS Austria 2008/09, authors' calculations.

Concerning parental leave opportunities, we find that the opportunity to take parental leave does not influence the childbearing plans of childless women but that of men. This might be explained by the fact that since 2002, parental leave payments do not dependent on previous employment and almost all mothers take parental leave - at least for a short period of time. ${ }^{9}$ The proportion of fathers on parental leave is rather low in Austria. Our results indicate that

\footnotetext{
${ }^{9}$ For an overview of parental leave legislation we refer to Gisser and Fliegenschnee (2004) and Prskawetz et al. (2008).
} 
the group of men for whom the opportunity to take parental leave is relevant for the childbearing decision process (21\%; see Table A2 in the Appendix) reports childbearing plans more often. The availability of child care is a further significant behavioural control aspect; it is negatively correlated with childbearing plans. This might be due to the fact that in Austria, combining work and family is difficult for women owing to the lack of public child care, the non-existence of a private child care market and the inconvenient opening hours of schools and many day-care institutions (Prskawetz et al. 2008, p. 323).

Let us now turn to the feeling of being ready. In the overall sample, the couple's feeling of being ready is a significant determinant for childbearing decisions. The estimated coefficient is 0.21 and significant at the 5\% level (Table 1, column 1). It indicates that childless persons who answered that the feeling of being ready for a child was important for their decision to have one more often wanted to become parents within the next three years as opposed to those who argued that readiness was not crucial for their childbearing decisions. Therefore, our results support hypothesis 1: the feeling of being ready is a determinant for fertility intentions.

Gender-specific calculations reveal an association between childbearing intentions and readiness among women significant at the 10\% level, whereas for men the estimated coefficient is not statistically different from zero. Although the estimated effect is positive and of similar magnitude as for women (male sample: 0.21; female sample: 0.28 ), we fail to get significant results. Therefore we have to reject hypothesis 2 : that the feeling of being ready is not gender-specific but perceived in the same way by men and women.

Although our descriptive results reveal that the feeling of being ready is more often seen as an important determinant for fertility decisions, we find in the multivariate framework that is it less important for childbearing intentions than economic aspects. The estimated coefficient for one's own work is larger in magnitude and has a higher statistical relevance. Therefore, we have to reject of hypothesis 3: that the feeling of being ready is more important for childbearing intentions than economic aspects.

Since the estimated coefficient for readiness is significant in the multivariate model including demographic characteristics as well as norms and attitudes which are embedded in the TPB, our results support hypothesis 4 : that the feeling of being ready has further explanatory power for childbearing decisions in the multifaceted framework of the TPB.

\section{Discussion}

The primary focus of this study was to broaden the understanding of the family formation process of childless men and women in Austria. We analysed fertility intentions by using a methodological triangulation. Starting with a qualitative approach we developed the idea that the issue of feeling ready for a child is a crucial element for fertility decisions. Readiness is considered to be mainly an emotional state of mind and to refer not only to the individual itself but also to the partner and to the couple as a unity.

Our quantitative results clearly support our conceptual framework which is based on the theory of planned behaviour. In the context of family formation, social norms, attitudes and behaviour control are significantly associated with childbearing intentions among childless men and women in Austria. Moreover, we included the aspect of readiness. It turned out to be an additional aspect for family formation with an explanatory power of its own. 
To our knowledge, the feeling of being ready has never been explicitly addressed with regard to the family formation process and fertility intentions. According to the results presented by Huinink et al. (2008) on childless men and women in Germany, "being personally ready" as well as "the partner has to be ready" are important preconditions for having a child and significantly associated with women's childbearing intentions. Only recently, Huinink and colleagues stated that "questions of why and when partners do or do not feel ready for children have yet to be answered" (Huinink et al. 2010, p. 10). Other qualitative studies mention the importance of the aspect of 'being ready' as well (Settersten 2007; Bernardi 2003; Rille-Pfeiffer 2009). Unfortunately, the authors do not further discuss this aspect.

Although our descriptive results revealed that readiness and a suitable partner were more often regarded as important determinants in the childbearing decision process than economic aspects, the preponderance of these individual factors was not confirmed by multivariate analyses. This might be partly explained by the fact that only a small group indicated that their decision of whether or not to have a child within the next three years depended only "a little" or "not at all" on the feeling of being ready. Although significant at a lower level, the feeling of being ready remains crucial for childbearing intentions. In our study we focused on the transition to parenthood, i.e. on the first child. Results not shown here revealed that the feeling of being ready and a suitable partner are important for higher parities as well, although less pronounced. In the context of family size intentions, a recent study underlined that not finding a suitable partner is an important factor (Liefbroer 2009).

Two limitations have to be mentioned. First, our qualitative analysis is based on childless persons who had been living with a partner for at least three years, whereas the quantitative analysis includes childless individuals regardless of their partner status. However, we ran our analyses only for those cohabiting with a partner. It turned out that the results based on this group were similar to the overall group of childless people. The magnitude of the estimated coefficient for the feeling of being ready as a couple was even more pronounced. In our quantitative analysis we included all childless men and women and controlled for the partner status in order to keep the sample as large as possible.

Second, in the quantitative survey we did not ask directly if respondents - and if appropriate, their partner or the couple as a unity-felt ready for a child. Therefore, we were not able to directly link the feeling of being ready with fertility intentions. As mentioned earlier, this implies that we are not able to fully incorporate it in the TPB and to theoretically analyse this aspect in the framework of the TPB. Although we have shown that readiness is an important aspect for the decision to have a child, our results remain empirical. Our qualitative results indicate that within the TPB, some parts of the readiness refer to attitudes, others to behavioural control. However, unless weights on the feeling of being ready are included, we can only speculate about the theoretical implementation in the TPB.

Based on the current study we would encourage future surveys on fertility to include not only readiness as a determinant of fertility intentions but also to ask directly whether respondents are ready or not for a child. With the implementation of additional items in the second wave of the Austrian GGS, we will be able to further analyse this aspect of 'being ready'. In addition, we suggest including readiness in the general GGS as well to allow country-specific analyses. 
Using a methodological triangulation, we provided a deeper insight in the feeling of being ready for a child within the context of family formation. Even if the quantitative data do not allow to measure all aspects mentioned in the qualitative study, our paper shows that blending qualitative and quantitative methods can definitely enrich demographic and family research. The current study was characterised by intensive and fruitful collaboration between a qualitatively and a quantitatively oriented researcher, which was very interesting and enlarged both co-authors' horizons. It was most interesting for the author applying quantitative methods to learn about qualitative approaches, to discuss them and to better understand this perspective. From our point of view, triangulating data is a valuable and promising innovative approach which should be considered for future research. 


\section{Literature}

Ajzen, I. 1988, Attitudes, personality and behavior. Open University Press, Milton Keyes.

Ajzen, I. 1991, 'The theory of planned behavior', Organizational Behavior and Human

Decision Processes, vol. 50, pp. 179-211.

Ajzen, I. and Fishbein, M. 2005, 'The influence of attitudes on behavior', in The handbook of attitudes, eds A. Dolores, B. T. Johnson and Z. M. P. Mahwah, Lawrence Erlbaum Associates, NJ, pp. 173-221.

Begley, C.M. 1996, 'Using triangulation in nursing research', Journal of Advanced Nursing, vol. 24, pp. 122-128.

Bernardi, L. 2003, 'Channels of social influence on reproduction', Population Research and Policy Review, vol. 22, no.5-6, pp. 527-555.

Bernardi, L. Keim, S. and Von der Lippe, H. 2007, 'Social influences on fertility: a comparative mixed methods study in Eastern and Western Germany', Journal of Mixed Methods Research, vol. 1, no. 1, pp. 23-47.

Bernardi, L., Klärner, A. and Von der Lippe, H. 2008, 'Job insecurity and the timing of parenthood: a comparison between eastern and western Germany', European Journal of Population, vol. 24, no. 3, pp. 287-313.

Billari, F. C., Philipov D. and Testa, M.R. 2009, 'Attitudes, Norms and Perceived Behavioural Control: Explaining Fertility Intentions in Bulgaria', European Journal of Population, vol. 25, no. 4, pp. 439-465.

Blossfeld, H.P., and Huinink, J. 2001, 'Lebensverlaufsforschung als sozialwissenschaftliche Forschungsperspektive. Themen, Konzepte, Methoden und Probleme', BIOS, vol. 14, pp. 5-31.

Borchardt, A. and Stöbel-Richter, Y. 2004, 'Die Genese des Kinderwunsches bei Paaren eine qualitative Studie', Materialien zur Bevölkerungswissenschaft, Bundesinstitut für Bevölkerungsforschung. Vol. 114.

Buber, I. 2010, 'Parity-Specific weights for the Austrian Generations and Gender Survey', VID Working Paper, vol. 4/2010. Available from: $<$ http://www.oeaw.ac.at/vid/download/WP2010 04.pdf $>$ [21. December 2010].

Burkart, G. 1994, Die Entscheidung zur Elternschaft, Ferdinand Enke Verlag, Stuttgart.

Campbell, D.T. and Fiske D.W. 1959, 'Convergent and discriminant validity by the multitraitmultimethod matrix', Psychological Bulletin, vol. 56, pp. 81-105.

Dommermuth, L., Klobas, J. and Lappegard, T. 2009, 'Now or later? The theory of planned behaviour and fertility intentions', Carlo F. Dondena Center for Research on Social Dynamics, DONDENA WORKING PAPERS.

Denzin, N.K. 1989, The research act. A theoretical introduction to sociological methods, 3rd edn, McGraw Hill, New York.

Fielding, N.G. and Fielding, J.L. 1986, Linking Data: the articulation of qualitative and quantitative methods in social research. Sage, London and Beverly Hills.

Flick, U. 1995, Qualitative Sozialforschung, Theorie, Methoden, Anwendung in Psychologie und Sozialwissenschaft. Rowohlt Taschenbuch Verlag, Reinbek bei Hamburg.

Flick, U. 2004, Triangulation - Eine Einführung. Reihe: Qualitative Sozialforschung, Band 12, Verlag für Sozialwissenschaften, Wiesbaden.

Flick, U. 2006, An introduction to qualitative research. Sage Publications, London.

Fliegenschnee, K. 2006a, 'Children should be a part of my life, but I don't know how to manage it.' Paper presented at European Population Conference, Liverpool.

Fliegenschnee, K. 2006b, 'There are simply always enough good reasons against having a child! Fears and worries about motherhood among childless, highly educated Austrian women', [CD-ROM] In: Rehberg, K. S. (ed.) Die Natur der Gesellschaft. 
Verhandlungsband des 33. Kongresses der Deutschen Gesellschaft für Soziologie 2006 in Kassel. Campus, Frankfurt/M.

Froschauer, U. and Lueger, M. 1992, Das Qualitative Interview: zur Analyse sozialer Systeme, WUV Universitätsverlag, Wien.

Gisser, R. and Fliegenschnee, K. 2004, Country report on general family-related policies and attitudes. Vienna Institute of Demography, internal paper.

Glaser, B. and Strauss, A. 1967, The discovery of grounded theory: strategies for qualitative research. Aldine Publishing Company, Chicago.

Helfferich, C., Klindworth, H. and Kruse, J. 2005, 'Männer leben - Eine Studie zu Lebensläufen und Familienplanung, Vertiefungsbericht.' Bundeszentrale für gesundheitliche Aufklärung (BZgA), Köln.

Hobcraft, J. and Kiernan, K. 1995, 'Becoming a parent in Europe', in European population conference, ed. EAPS-IUSSP, Franco Angeli, Milan, pp. 27-65.

Huinink, J., Schröder T. and Boehnke, M. 2008, 'Kinderwunsch und Familiengründung: Die Bedeutung von Voraussetzungen und Entscheidungsgrundsätzen', in Neuere Entwicklungen in der Beziehungs- und Familienforschung. Vorstudien zum Beziehungs- und Familienentwicklungspanel (PAIRFAM), eds. M. Feldhaus and J. Huinink, Ergon Verlag, Würzburg, pp. 321-350.

Huinink, J., Brüderl, J., Nauck, B., Walper, S., Castiglioni, L. and Feldhaus, M. 2010, 'Panel Analysis of Intimate Relationships and Family Dynamics (pairfam) - Conceptual Framework and Design', pairfam-Arbeitspapier vol. 17. Universitäten Bremen, Mannheim, Chemnitz und München.

Keim, S., Klärner, A. and Bernardi, L. 2009, 'Qualifying social influence on fertility intentions: composition, structure, and meaning of fertility-relevant social networks in western Germany', Current Sociology vol. 57, no. 6, pp. 888-907.

Kelle, U., 2001. 'Sociological explanations between micro and macro and the integration of qualitative and quantitative method', Forum Qualitative Sozialforschung, vol. 2, no. 1. Available from:

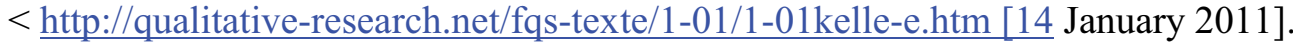

Klobas, J. 2010, 'Social psychological influences on fertility intentions: A study of eight countries in different social, economic and policy contexts', Carlo F. Dondena Centre for Research on Social Dynamics.

Lamnek, S. 1995. Qualitative Sozialforschung Band 2: Methoden und Techniken, Beltz, Weinheim.

Liefbroer, A.C. 2005, 'The Impact of Perceived Costs and Rewards of Childbearing on Entry into Parenthood: Evidence from a Panel Study', European Journal of Population, vol. 21, pp. 367-391.

Liefbroer, A.C. 2009, 'Changes in Family Size Intentions Across Young Adulthood: A LifeCourse Perspective', European Journal of Population, vol. 25, pp. 363-386.

Lutz, W. 2005, 'Life expectancy still raising and Italians have fewer "bambini" ', Framtider (English edition), vol. 2, pp. 19-24.Maiwald, K.-O. 2005, 'Competence and Praxis: Sequential Analysis in German Sociology', Forum Qualitative Social Research [Online], vol. 6, no. 3, Available from: $<$ http://www.qualitativeresearch.net/index.php/fqs/article/viewArticle/21> [21. December 2010].

Maul, K., Huinink J. and Schröder, T. (forthcoming), 'Elternschaftsentscheidungen im Spannungsfeld beruflicher und familiärer Planungen', in Partnerschaften und die Beziehungen zu Eltern und Kindern. eds. S. Walper, Sabine and E.-V. Wendt, Ergon, Würzburg

Mayring, P. 1990, Einführung in die qualitative Sozialforschung. Eine Anleitung zum qualitativen Denken, Psychologie Verlags Union, München. 
Miller, W.B. and Pasta, D.J. 1994, 'The psychology of child timing: A measurement instrument ans a model', Journal of Applied Social Psychology, vol. 24, pp. 218-250.

Miller, W.B. and Pasta, D.J. 1995, 'Behavioural intentions: Which ones predict fertility behaviour in married couples?', Journal of Applied Social Psychology, vol. 25, pp. 530-555.

Müller-Burhop, M. 2008, Elternwünsche. Eine empirische Studie über Wünsche und Vorstellungen junger Eltern und daraus folgende Konsequenzen für Politik und Gesellschaft, Ergon, Würzburg.

Philipov, D., Spéder, Z. and Billari, F. 2006, 'Soon, later, or ever? The impact of anomie and social capital on fertility intentions in Bulgaria (2002) and Hungary (2001)', Population Studies, vol. 60, no. 3, pp. 289-308.

Philipov, D., Thévenon, O., Klobas, J., Bernardi, L. and Liefbroer, A. 2009, 'Reproduction Decision-Making in a Macro-Micro Perspective (REPRO) State-of-the-Art Review', E. D. R. Papers. Vienna, Vienna Institute of Demography of the Austrian Academy of Sciences. 1.

Prskawetz, A., Sobotka, T., Buber, I., Engelhardt, H. and Gisser, R. 2008, 'Austria: Persistent low fertility since the mid-1980s. ' Demographic Research, Special Collection 7, vol. 19, no. 12, pp. 293-360. Available from: <http://www.demographicresearch.org/Volumes/Vol19/12/> [21. December 2010].

Rille-Pfeiffer, C. 2009, Kinder - jetzt, später oder nie? Generatives Verhalten und Kinderwunsch in Österreich, Schweden und Spanien. Schriftenreihe des Österreichischen Instituts für Familienforschung (ÖIF) 21, Budrich UniPress, Vienna.

Schoen, R., Astone, N.M., Kim, Y.J., Nathanson, C.A. and Fields, J.M. 1999, 'Do fertility intentions affect fertility behavior?' Journal of Marriage and the Family, vol. 61, pp. 760-799.

Settersten, R.A., Jr. 2007, 'Passages to adulthood: Linking demographic change and human development', European Journal of Population, vol. 23, pp. 251-272.

Settersten R.A., Jr. (forthcoming), 'Becoming adult: Meanings and markers for young Americans', in Coming of age in America. eds M. Waters, J. Holdaway, M. Kefalas, and P. Carr, University of California Press, Berkeley.

Spielauer, M. 2004. 'Childlessness and the concentration of reproduction in Austria', MPIDR Working Paper WP 2004-028, Rostock: Max Planck Institute for Demographic Research.

Strauss, A. 1991, Grundlagen qualitativer Sozialforschung, Fink, München.

Strauss, A. and Corbin, J. 1996, Grounded Theory: Grundlagen Qualitativer Sozialforschung Psychologie Verlags Union, Weinheim.

Vikat, A., Spéder, Z., Beets, G., Billari, F. C., Bühler, C., Désesquelles, A., Fokkema, T., Hoem, J.M., MacDonald, A. L., Neyer, G.R., Pailhé, A., Pinnelli, A. and Solaz, A. 2007, 'Generations and Gender Survey (GGS): towards a better understanding of relationships and processes in the life course'. Demographic Research vol. 17, no. 14, pp. 389-440. Available from: <http://www.demographicresearch.org/Volumes/Vol17/14/17-14.pdf> [21. December 2010].

Von der Lippe, H. 2010, 'Motivation and selection processes in a biographical transition: A psychological mixed methods study on the transition into fatherhood', Journal of Mixed Methods, vol 4, no. 3, pp. 199-221.

Witzel, A. 2000. 'Das problemzentrierte Interview', Forum: qualitative social research, vol. 1, no. 1. Available from:

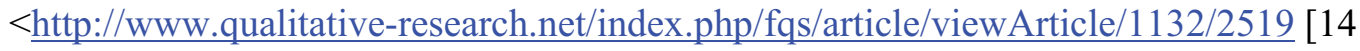
January 2011]. 


\section{Appendix Table A1}

Sample characteristics (in per cent)

All childless Childless men Childless women

Age

$18-24$

25-29

30-34

35-39

40-44

\section{4}

23

14

11

8

Partner status

No partner

Living with partner in same household

Living apart together

Highest educational level

ISCED $1+2$

ISCED 3

ISCED 4

ISCED 5+6

N (total)

\section{5}

22

33

12

52

18

18

1,086
41

23

15

12

8

50

18

32

13

58

15

15

999
47

23

12

10

8

39

27

34

11

45

22

23

2,086

\section{Appendix Table A2}

Perceived behaviour control; dependence of childbearing decision on various factors (in per cent)

\begin{tabular}{l|l|cccc} 
& & A great deal/quite a lot & A little & Not at all & Total \\
\hline Financial situation & Men & 38 & 33 & 29 & 100 \\
& Women & 44 & 31 & 26 & 100 \\
\hline Own job & Men & 28 & 27 & 45 & 100 \\
& Women & 45 & 27 & 29 & 100 \\
\hline Housing situation & Men & 37 & 27 & 38 & 100 \\
& Women & 35 & 28 & 35 & 100 \\
\hline Health & Men & 36 & 27 & 38 & 100 \\
& Women & 44 & 21 & 43 & 100 \\
\hline Suitable partner & Men & 78 & 19 & 37 & 100 \\
& Women & 77 & 8 & 14 & 100 \\
\hline Partner's job & Men & 31 & 5 & 18 & 100 \\
& Women & 32 & 39 & 31 & 100 \\
\hline Partner's health & Men & 64 & 27 & 41 & 100 \\
& Women & 54 & 17 & 19 & 100 \\
\hline Child care & Men & 35 & 19 & 26 & 100 \\
& Women & 46 & 36 & 29 & 100 \\
\hline Parental leave & Men & 21 & 30 & 24 & 100 \\
& Women & 56 & 31 & 48 & 100 \\
\hline Ready for a child & Men & 70 & 20 & 23 & 100 \\
& Women & 82 & 19 & 11 & 100 \\
\hline Partner is ready & Men & 78 & 9 & 10 & 100 \\
& Women & 81 & 14 & 8 & 100 \\
\hline Ready as a couple & Men & 80 & 12 & 10 & 100 \\
& Women & 85 & 7 & 100 \\
\hline
\end{tabular}




\section{Appendix Table A3}

Factor loading and uniqueness of items of attitudes and norms

\begin{tabular}{|c|c|c|c|c|}
\hline & $\begin{array}{l}\text { Factor 1: } \\
\text { Norms }\end{array}$ & $\begin{array}{l}\text { Factor 2: Pos. } \\
\text { attitudes }\end{array}$ & $\begin{array}{l}\text { Factor 3: Neg. } \\
\text { attitudes }\end{array}$ & Uniqueness \\
\hline \multicolumn{5}{|c|}{$\begin{array}{l}\text { Although you may feel that the decision to have a child is yours }[\ldots] \text {, it is likely that others } \\
\text { have opinions about what you should do. [...] To what extent do you agree or disagree with } \\
\text { the following statements }\end{array}$} \\
\hline $\begin{array}{l}\text { Most of your friends think that you } \\
\text { should have a child. }\end{array}$ & 0.7867 & 0.1066 & 0.0123 & 0.3696 \\
\hline $\begin{array}{l}\text { Your parents think that you should } \\
\text { have a child. }\end{array}$ & 0.8551 & 0.0343 & 0.1040 & 0.2569 \\
\hline $\begin{array}{l}\text { Most of your relatives think that } \\
\text { you should have a child. }\end{array}$ & 0.8845 & 0.0620 & 0.0176 & 0.2134 \\
\hline \multicolumn{5}{|c|}{ Suppose you will have a child during the next three years, how would this affect } \\
\hline $\begin{array}{l}\text { The possibility to do what you } \\
\text { want. }\end{array}$ & 0.2267 & 0.5784 & 0.1511 & 0.5912 \\
\hline Your employment opportunities. & 0.0983 & 0.5229 & 0.1792 & 0.6848 \\
\hline Your financial situation. & 0.0939 & 0.5466 & 0.1379 & 0.6734 \\
\hline Your sexual life. & 0.0474 & 0.3912 & 0.1383 & 0.8256 \\
\hline What people around think of you. & 0.2021 & 0.1212 & 0.3328 & 0.8337 \\
\hline $\begin{array}{l}\text { The joy and satisfaction you get } \\
\text { from life. }\end{array}$ & 0.1893 & 0.3215 & 0.5650 & 0.5415 \\
\hline $\begin{array}{l}\text { The closeness between you and } \\
\text { your partner. }\end{array}$ & 0.0049 & 0.2090 & 0.6051 & 0.5901 \\
\hline $\begin{array}{l}\text { The care and security you may } \\
\text { have in old age. }\end{array}$ & -0.0027 & -0.0822 & 0.3322 & 0.8829 \\
\hline $\begin{array}{l}\text { The closeness between you and } \\
\text { your parents. }\end{array}$ & 0.1251 & -0.0934 & 0.4157 & 0.8028 \\
\hline
\end{tabular}

Remark: For several items, uniqueness is rather high (0.80 to 0.88). In general, uniqueness is the percentage of variance for the variable that is not explained by the common factor. High uniqueness means that the variable is not well explained by that particular factor. This is the case for "sexual life", "what other people think of you", "care and security in old age" and "closeness between you and your parents". We nevertheless kept these items. Sensitivity analysis in the multivariate model revealed no different results when excluding these items for the construction of factors. The number of observations was only 1.578, since the item "closeness with partner" had many "not applicable" for those who had no partner at the time of the interview. Unfortunately, response of those without a partner did not answer consistently. Whereas two out of three evaluated their perceived attitude, one-third answered with "not applicable" which was recoded as a missing value for the factor analysis. Missing values for other variables included in the factor analysis reduced the original number of 2.086 childless respondents to 1.578 for the factor analysis. In order to avoid the exclusion of a quarter of our observations for the probit regressions (Table 1), we included the items in the calculation of the means if available and neglected them if missing. 


\section{Appendix: Additional Information on Theoretical Sampling}

The basis for sampling is theoretical sampling. It is not a random sample but based on conscious decisions. Interviewees are chosen because of earlier theoretical considerations and because issues or ideas have come up during the research process. (Lamnek 1995). Which persons will fit the study later on is decided during the research process and there are no restrictions from the beginning.

One of the major factors why people postpone their wish to have a child is their education

level: women with higher qualifications need more time to complete their education and also often intend to work for a certain time before having children. However, they not only wait until higher ages to get children - Lutz (2005) also reports that in western Germany around 40 percent of women with tertiary education are expected to end up childless. In Austria around $30 \%$ of all highly educated women are childless and this figure has been relatively stable over the years (Spielauer 2004). Looking at highly educated persons and understanding why they have chosen a childless life up to now - and who or what influenced them in this choice-was the starting point of this research.

Because postponement of the first child was of interest for this research, it was decided to interview women and men around age 30 . At this age, it is very likely that they have already taken conscious decisions concerning their fertility in one or the other direction. Other prerequisites were that they should have no children and should live in a partnership. It was also decided to start with a very homogeneous group (highly educated, living and/or working in Vienna). Based on our findings we assumed that less educated people may have less thoughts about their fertility decisions and that it would be interesting to include them as well. However, we only had very few less educated persons in our sample.

In this project, the snowball sampling method was used: I wrote an email message to everybody I knew and asked them to forward it to their friends. Attached was a description of what I was looking for, i.e., persons around 30 who were living in a relationship and did not have any children so far; additionally they should not know me personally. Several persons replied and interviews were conducted first with women holding a university degree. Later I aimed for their partners, to cover the male perspective as well; not all of them agreed to an interview, however, and in one case the couple had already split up. In a second wave I also tried to get less educated individuals and focused more on the issue that I wanted to interview the partner as well. The interviews took place at the interviewee homes, over a coffee at the VID or at my place. I let the interviewees decide where they wanted to be interviewed so as to make the situation as comfortable as possible for them. 


\section{VIENNA INSTITUTE OF DEMOGRAPHY}

\section{Working Papers}

Fent, Thomas, Belinda Aparicio Diaz, and Alexia Prskawetz, Family Policies in the Context of Low Fertility and Social Structure, VID Working Paper 02/2011.

Buber, Isabella, Caroline Berghammer, and Alexia Prskawetz, Doing Science, Forgoing Childbearing? Evidence from a Sample of Female Scientists in Austria, VID Working Paper 01/2011.

Strulik, Holger, Klaus Prettner, and Alexia Prskawetz, R\&D-Based Growth in the Post-Modern Era, VID Working Paper 09/2010.

Prettner, Klaus and Alexia Prskawetz, Demographic Change in Models of Endogenous Economic Growth. A Survey, VID Working Paper 08/2010.

Flandorfer, Priska, Christian Wegner, and Isabella Buber, Gender Roles and Smoking Behaviour, VID Working Paper 07/2010.

Barakat, Bilal, Johannes Holler, Klaus Prettner, and Julia Schuster, The Impact of the Economic Crisis on Labour and Education in Europe, VID Working Paper 06/2010.

Grafeneder-Weissteiner, Theresa and Klaus Prettner, Agglomeration Processes in Ageing Societies, VID Working Paper 05/2010.

Buber, Isabella, Parity-specific weights for the Austrian Generations and Gender Survey, VID Working Paper 04/2010.

Testa, Maria Rita, She wants, he wants: Couple's childbearing desires in Austria, VID Working Paper 03/2010.

Buber, Isabella, Wissenschaftlerinnen in Österreich - Zusatzerhebung im Rahmen des GGS.Dokumentation der Datenerhebung und deskriptive Ergebnisse, VID Working Paper 02/2010.

Kuhn, Michael, Stefan Wrzaczek, Alexia Prskawetz, and Gustav Feichtinger, Externalities in a Life-Cycle Model with Endogenous Survival, VID Working Paper $01 / 2010$.

Prettner, Klaus, Population Ageing and Endogenous Economic Growth, VID Working Paper 08/2009.

The Vienna Institute of Demography Working Paper Series receives only limited review. Views or opinions expressed herein are entirely those of the authors. 